\title{
FUNGISTATIC PROPERTIES OF GRANULATED BLASTFURNACE SLAG AND RELATED SLAG-CONTAINING CEMENTS
}

\author{
\#JÚLIUS STRIGÁČ, PAVEL MARTAUZ \\ Považská cementáreň, a. s. Ladce, J. Král’a, 01863 Ladce, Slovakia \\ ${ }^{\#}$ E-mail: strigac.j@pcla.sk
}

Submitted October 14, 2015; accepted December 21, 2015

\begin{abstract}
Keywords: Mould proofness properties, Fungistatic properties, Ground granulated blastfurnace slag, Fungistatic cements
The article deals with studying the antifungal effect of ground granulated blastfurnace slag (GGBS) and the cements made from it. Antifungal effects were tested on the fungi using the procedure given in the Czech national standard C SN 724310 : 1977 - Testing the mould proofness properties of building products and materials. A mixture of the fungi Aspergillus niger, Chaetomium globosum, Penicillium funiculosum, Paecilomyces variotii and Gliocladium virens was used for testing. The scale for evaluating mould proofness properties according to ČSN 72 4310: 1977 is from 0 to 5 in degree of fungi growth, where a value of 0 means that no growth of fungi occurs and the building products and materials possess fungistatic properties. The study confirms the fungistatic propeties of GGBS with mould proofness property 0. The addition of GGBS to cements from $65 \mathrm{wt}$. \% to $95 \mathrm{wt}$. \% ensures the achieving of a fungistatic environment, which enables the production of fungistatic blastfurnace cements CEM III/A 32,5 N (with GGBS content of $65 \mathrm{wt}$ \%), CEM III/B 32,5 N and CEM III/C $32,5 \mathrm{~N}$ with mould proofness property 0 .
\end{abstract}

\section{INTRODUCTION}

The presence of microorganisms such as fungi in building materials is a serious problem not only in regard of hygienic, health and aesthetic issues, but also due to biodeterioration of the materials [1-3]. Biological corrosion of concretes is a serious problem wherever conditions suitable for a life of the particular microorganisms - such as the temperature, $\mathrm{pH}$ and moisture of the environment, the presence of oxygen, radiation, the input of nutrients and others - have come into existence. Biodeterioration reduces the utility properties of concretes and shortens their service-life. Biological corrosion, as a specific type of chemical corrosion, is caused by various biogenic organic acids and mineral acids (sulphuric acid $\mathrm{H}_{2} \mathrm{SO}_{4}$, nitric acid $\mathrm{HNO}_{3}$ ) as well as by corrosive hydrogen sulphide $\mathrm{H}_{2} \mathrm{~S}$ and ammonia $\mathrm{NH}_{3}$, which result from the metabolic activity of microorganisms [1-3].

Biodeterioration of concrete structures is mostly caused by aerobic sulphur-oxidizing bacteria, which oxidize sulphurous compounds to sulphuric acid $\mathrm{H}_{2} \mathrm{SO}_{4}$, and anaerobic sulphate-reducing bacteria, which reduce sulphates to form $\mathrm{H}_{2} \mathrm{~S}$, a corrosive gas and a precursor for further formation of $\mathrm{H}_{2} \mathrm{SO}_{4}$ by the activity of sulphur bacteria. Sulphuric acid $\mathrm{H}_{2} \mathrm{SO}_{4}$ reacts with the calcium compounds of hydrated cement compounds leading to the formation of $\mathrm{CaSO}_{4}$, or $\mathrm{CaSO}_{4} \cdot 2 \mathrm{H}_{2} \mathrm{O}$, which can cause sulphate degradation of concrete. Two types of sulphate degradation can be distinguished - gypsum and sulphoaluminate. A great increase in the volume of the corrosion products occurs during both types of sulphate degradation, and this causes extreme expansion in the concrete and leads to complete destruction of concrete's structural elements $[2,3]$. With gypsum corrosion the volume nearly doubles. Monosulphate $3 \mathrm{CaO} \cdot \mathrm{Al}_{2} \mathrm{O}_{3} \cdot \mathrm{CaSO}_{4} \cdot 12 \mathrm{H}_{2} \mathrm{O}$ or ettringite $3 \mathrm{CaO} \cdot \mathrm{Al}_{2} \mathrm{O}_{3} \cdot 3 \mathrm{CaSO}_{4} \cdot 31-32 \mathrm{H}_{2} \mathrm{O}$ is formed as the end product by the reaction of gypsum with $3 \mathrm{CaO}$. - $\mathrm{Al}_{2} \mathrm{O}_{3} \cdot 6 \mathrm{H}_{2} \mathrm{O}$ during sulphoaluminate corrosion, and the volume of the reaction products increases fourfold.

Nitrifying bacteria oxidize ammonia $\mathrm{NH}_{3}$ into nitric acid $\mathrm{HNO}_{3}$ via nitrous acid $\mathrm{HNO}_{2}[2,3]$. The action of $\mathrm{HNO}_{3}$ on the calcareous binding material of concrete results in the formation of calcium nitrate $\mathrm{Ca}\left(\mathrm{NO}_{3}\right)_{2}$ - a water soluble salt that can be washed out from the concrete matrix, which can lead to an increase in the number of pores and capillaries, thus degradation of the strength of concretes.

Biogenic high-molecular organic acids, such as humic acid or pyruvic acid, and biogenic low-molecular organic acids, such as formic acid, acetic acid, propionic acid, butyric acid, lactic acid, oxalic acid, malic acid, citric acid and others $[4,5]$, are formed by the activity of certain chemoorganotrophic bacteria and fungi. In some cases the chemical corrosive effect of organic acids is even higher than that of $\mathrm{H}_{2} \mathrm{SO}_{4}$ [6]. These acidic metabolites react mainly with the calcerous components 
of concrete and mortar stone through the formation of their non-binding calcerous salts, thus causing degradation into the depth of the matrix. In some cases, they can also react with the components of aggregates and in other cases with admixtures and additives.

The resistance of concrete samples made from various kinds of binders to acid attack for concretes of chemical-attack classes XA1 - XA3 was studied in [6] with the use of sulphuric acid $(\mathrm{pH}=2)$ and a mixture of organic acids $(\mathrm{pH}=3)$. Alkali-activated binders so-called geopolymers resisted acid attack well in both cases, in contrast to the blastfurnace cements CEM III/A 32,5 N and CEM III/B 32,5 N, which contain a high volume of ground granulated blastfurnace slag (GGBS).

Biofouling caused by the deposits of microorganisms, such as bacteria, fungi, mosses and lichens, also devalues the aesthetic appearance of concrete constructions. In addition, biofouling promotes biocorrosion of exposed steel reinforcement parts of concretes via an electrochemical as well as a chemical mechanism, depending on the aerobic and anaerobic conditions of a wet environment [7].

Alkali-activated GGBS in a mixture with calcined kaolinitic clay showed good resistance and structural stability with respect to adverse environmental conditions, such as rapid changes of temperature and humidity as well as microbial and chemical aggression [8]. As GGBS increases the chemical resistance of cements with its glassy phase, it also increases resistance to acidic metabolites of microorganisms in the form of mineral and organic acids.

Tests of the resistance of concrete samples made from cements with various $\mathrm{CaO}$ content and exposed to an aggressive environment of water sludge with low acidity and carbonate content in the nitrification basins of a wastewater treatment plant indicated that the resistance to biological corrosion decreased with the reduction of $\mathrm{CaO}$ content in the cements and by the increased addition of GGBS in the order CEM I, CEM II/A-S, CEM III/B, due to the smaller protective layer of precipitated $\mathrm{CaCO}_{3}$ that formed on the concrete surfaces [1].

The effect of concrete properties and nutrients on fungal colonization and fouling with the use of different concrete compositions was studied in work [9]. The effect of adding GGBS in varying amounts of $10 \%, 25 \%$ and $50 \%$ was investigated, with the results indicating that GGBS had only a small effect against fungi.
In current antimicrobial cement containing mixtures, GGBS is used only as a latent hydraulic addition or as a filler, disregarding its other application possibilities. One such example is the cement mixture based on calcium aluminate cement, fine GGBS and the antibacterial additive based on $\mathrm{Ag}^{+}$and/or $\mathrm{Cu}^{2+}$ according to [10]. Another is the cement mixture based on calcium aluminate compounds and colemanite (colemanite mineral is hydrated calcium triborate $\mathrm{Ca}\left[\mathrm{B}_{3} \mathrm{O}_{4}(\mathrm{OH})_{3}\right] \cdot \mathrm{H}_{2} \mathrm{O}$ ), which also includes one or more kinds of additions, such as fine GGBS, fly ash, silica fume and possibly inorganic salts according to [11]. Also worth mentioning is an antibacterial penetration hardening agent for the maintenance of stone constructions, 1 to $12 \%$ of which is made up of antibacterial organic compounds and inorganic fillers consisting of pulverized stone powder, particles of GGBS, portland cement, gypsum and inorganic pigments according to [12]. Finally, there is an algae- and mould-resistant concrete mixture composed of cement and aggregates including at least one other material, such as silica fume, fly ash and fine GGBS, into which a selective organic herbicide and/or inorganic metallic ion antibacterial agent is added in the amount of 0.3 to $6 \mathrm{~kg} \cdot \mathrm{m}^{-3}$ of concrete mixture according to [13].

Until now, GGBS has been used in antimicrobial applications only as an addition for increasing chemical resistance to the acidic metabolites of microorganisms such as $\mathrm{H}_{2} \mathrm{SO}_{4}, \mathrm{H}_{2} \mathrm{~S}, \mathrm{HNO}_{3}$ and biogenic organic acids $[2,3]$.

However, more recently GGBS has been found to possess higher antimicrobial potential than was previously thought [14-16]. Therefore, in this paper, the antimicrobial potential of GGBS as a form of mould proofness agent was studied in detail as well as the effect of GGBS addition to cement for achieving antifungal properties.

\section{EXPERIMENTAL}

\section{Materials}

In the experiments, granulated blastfurnace slag, blastfurnace cements (CEM III/A 32,5 N, CEM III/B 32,5 N, CEM III/C 32,5 N), Portland-slag cements (CEM II/A-S 42,5 R, CEM II/B-S 32,5 R) and Portland cement (CEM I 42,5 N) were used, as well as mixtures of ground granulated blastfurnace slag (GGBS) with ground Portland cement clinker (PCC) and gypsum for

Table 1. Chemical composition of ground granulated blastfurnace slag (GGBS), Portland cement clinker (PCC) and gypsum in wt. \% used for testing.

\begin{tabular}{lccccccccc}
\hline wt. $\%$ & $\mathrm{CaO}$ & $\mathrm{SiO}_{2}$ & $\mathrm{Al}_{2} \mathrm{O}_{3}$ & $\mathrm{Fe}_{2} \mathrm{O}_{3}$ & $\mathrm{MgO}$ & $\mathrm{SO}_{3}$ & $\mathrm{~K}_{2} \mathrm{O}$ & $\mathrm{Na}_{2} \mathrm{O}$ & L.O.I.* \\
\hline GGBS & 38.1 & 39.5 & 6.8 & 0.7 & 9.6 & 1.8 & 0.4 & 0.6 & 0.9 \\
PCC & 65.8 & 20.9 & 4.6 & 3.4 & 1.3 & 0.5 & 0.9 & 0.1 & 1.0 \\
Gypsum & 31.9 & 0.4 & 0.2 & 0.2 & 0.02 & 45.9 & 0.07 & 0.05 & 21.1 \\
\hline
\end{tabular}

* L.O.I. - loss of ignition 
producing cement compositions according to European standard EN 197-1: 2011 [17]. The chemical composition of PCC and gypsum is given in Table 1. GGBS, which is usually used in cement production, has been characterized as having glassy phase content of $97 \mathrm{wt} . \%$; its chemical composition is also reported in the Table 1. The glassy phase content in GGBS was determined by light microscopy $[18,19]$, which was supplemented by

Table 2. Chemical composition of water leaches from ground granulated blastfurnace slag (GGBS) at $20^{\circ} \mathrm{C}$ and $100^{\circ} \mathrm{C}$.

\begin{tabular}{|c|c|c|c|}
\hline Parameter & $\begin{array}{c}\text { Measured } \\
\text { unit }\end{array}$ & $\begin{array}{c}\text { Water leach } \\
20^{\circ} \mathrm{C}\end{array}$ & $\begin{array}{c}\text { Water leach } \\
100^{\circ} \mathrm{C}\end{array}$ \\
\hline $\mathrm{CN}^{-}$total & {$\left[\mathrm{mg} \cdot \mathrm{l}^{-1}\right]$} & $<0.005$ & 0.020 \\
\hline $\mathrm{Cl}^{-}$ & {$\left[\mathrm{mg} \cdot \mathrm{l}^{-1}\right]$} & 7.3 & 14.2 \\
\hline $\mathrm{F}^{-}$ & {$\left[\mathrm{mg} \cdot \mathrm{l}^{-1}\right]$} & 0.53 & 0.58 \\
\hline$\left(\mathrm{SO}_{4}\right)^{2-}$ & {$\left[\mathrm{mg} \cdot \mathrm{l}^{-1}\right]$} & 121 & 147 \\
\hline $\mathrm{S}^{2-}$ & {$\left[\mathrm{mg} \cdot \mathrm{l}^{-1}\right]$} & 0.81 & 1.43 \\
\hline$\left(\mathrm{NO}_{3}\right)^{-}$ & {$\left[\mathrm{mg} \cdot \mathrm{l}^{-1}\right]$} & $<1$ & $<1$ \\
\hline$\left(\mathrm{NO}_{2}\right)^{-}$ & {$\left[\mathrm{mg} \cdot \mathrm{l}^{-1}\right]$} & 0.23 & 0.23 \\
\hline$\left(\mathrm{HCO}_{3}\right)^{-}$ & {$\left[\mathrm{mg} \cdot \mathrm{l}^{-1}\right]$} & $<0.3$ & $<0.3$ \\
\hline$\left(\mathrm{NH}_{4}\right)^{+}$ & {$\left[\mathrm{mg} \cdot \mathrm{l}^{-1}\right]$} & 0.38 & 1.01 \\
\hline K & {$\left[\mathrm{mg} \cdot \mathrm{l}^{-1}\right]$} & 11.2 & 18.2 \\
\hline $\mathrm{Na}$ & {$\left[\mathrm{mg} \cdot \mathrm{l}^{-1}\right]$} & 5.54 & 8.24 \\
\hline $\mathrm{Cd}$ & {$\left[\mu \mathrm{g} \cdot 1^{-1}\right]$} & $<0.3$ & $<0.3$ \\
\hline $\mathrm{Ba}$ & {$\left[\mathrm{mg} \cdot \mathrm{l}^{-1}\right]$} & 0.100 & 0.239 \\
\hline As & {$\left[\mu \mathrm{g} \cdot 1^{-1}\right]$} & $<1$ & $<1$ \\
\hline Cr total & {$\left[\mu \mathrm{g} \cdot 1^{-1}\right]$} & 19 & 16 \\
\hline $\mathrm{Cr}^{6+}$ & {$\left[\mu \mathrm{g} \cdot 1^{-1}\right]$} & $<10$ & $<10$ \\
\hline $\mathrm{Cu}$ & {$\left[\mu \mathrm{g} \cdot 1^{-1}\right]$} & $<2$ & $<2$ \\
\hline $\mathrm{Ni}$ & {$\left[\mu \mathrm{g} \cdot 1^{-1}\right]$} & $<2$ & $<2$ \\
\hline $\mathrm{Pb}$ & {$\left[\mu \mathrm{g} \cdot 1^{-1}\right]$} & $<5$ & $<5$ \\
\hline $\mathrm{Sb}$ & {$\left[\mu \mathrm{g} \cdot 1^{-1}\right]$} & $<1$ & $<1$ \\
\hline $\mathrm{Se}$ & {$\left[\mu \mathrm{g} \cdot 1^{-1}\right]$} & $<1$ & $<1$ \\
\hline $\mathrm{Te}$ & {$\left[\mu \mathrm{g} \cdot 1^{-1}\right]$} & 120 & $<50$ \\
\hline V & {$\left[\mu \mathrm{g} \cdot 1^{-1}\right]$} & 6 & $<3$ \\
\hline $\mathrm{Zn}$ & {$\left[\mu \mathrm{g} \cdot 1^{-1}\right]$} & $<3$ & $<3$ \\
\hline $\mathrm{Hg}$ & {$\left[\mu \mathrm{g} \cdot 1^{-1}\right]$} & 0.7 & 0.9 \\
\hline $\mathrm{Be}$ & {$\left[\mu \mathrm{g} \cdot 1^{-1}\right]$} & $<0.1$ & $<0.1$ \\
\hline Sn & {$\left[\mu \mathrm{g} \cdot \mathrm{l}^{-1}\right]$} & $<30$ & $<30$ \\
\hline $\mathrm{Li}$ & {$\left[\mathrm{mg} \cdot \mathrm{l}^{-1}\right]$} & 0.03 & 0.07 \\
\hline Co & {$[\mu \mathrm{g} / 1]$} & $<2$ & $<2$ \\
\hline $\mathrm{Mn}$ & {$\left[\mathrm{mg} \cdot \mathrm{l}^{-1}\right]$} & 0.133 & $<0.002$ \\
\hline Mo & {$\left[\mu \mathrm{g} \cdot 1^{-1}\right]$} & $<4$ & $<4$ \\
\hline $\mathrm{Tl}$ & {$\left[\mu \mathrm{g} \cdot 1^{-1}\right]$} & $<50$ & $<50$ \\
\hline PCB & {$\left[\mu \mathrm{g} \cdot \mathrm{l}^{-1}\right]$} & $<0.01$ & $<0.01$ \\
\hline PAU & {$\left[\mu \mathrm{g} \cdot \mathrm{l}^{-1}\right]$} & 0.210 & 0.375 \\
\hline $\mathrm{pH}$ & & 11.54 & 11.63 \\
\hline
\end{tabular}

X-ray diffraction method [20]. Therefore the crystalline and glassy components of 1000 slag grains (fraction $40-63 \mu \mathrm{m}$ ) were counted as well as they were analysed by X-ray diffraction. The GGBS was ground to the specific surface area of $400 \mathrm{~m}^{2} \cdot \mathrm{kg}^{-1}$. Some small parts of GGBS were water leached at $20^{\circ} \mathrm{C}$ and $100^{\circ} \mathrm{C}$. The chemical composition of the GGBS water leaches is shown in Table 2.

The mineralogical composition of the constituents is:

- GGBS is fully glassy; however, sometimes it can contain a small amount of crystalline melilite (solid solution of gehlenite $\mathrm{C}_{2} \mathrm{AS}$ and akermanite $\mathrm{C}_{2} \mathrm{MS}_{2}$ ) or merwinite $\mathrm{C}_{3} \mathrm{MS}_{2}$;

- $\mathrm{PCC}$ is composed of clinker minerals $\mathrm{C}_{3} \mathrm{~S}$ (70.5 wt. \%), $\mathrm{C}_{2} \mathrm{~S}$ (10.2 wt. \%), $\mathrm{C}_{3} \mathrm{~A}$ (5.7 wt. \%), $\mathrm{C}_{4} \mathrm{AF}$ (10.9 wt. \%) and free lime $\mathrm{CaO}(1.0$ wt.\%);

- gypsum is mineralogically almost completely gypsum $\mathrm{CaSO}_{4} \cdot 2 \mathrm{H}_{2} \mathrm{O}$ (min. 95 wt. \%), with only a minimum amount of unreacted limestone $\mathrm{CaCO}_{3}$ content (max. 2.5 wt. \%), which is a precipitate by-product of titanium white $\mathrm{TiO}_{2}$ production by leaching ilmenite $\mathrm{FeTiO}_{3}$ with sulfuric acid $\mathrm{H}_{2} \mathrm{SO}_{4}$ and subsequent neutralization of $\mathrm{H}_{2} \mathrm{SO}_{4}$ with limestone $\mathrm{CaCO}_{3}$ (from manufacturer).

The contents of the mixtures of GGBS, PCC and gypsum are given in Table 3 . The proportion of GGBS to PCC in the mixtures is in agreement with the proportions expressed in European standard EN 197-1: 2011 [17]. The amount of the gypsum added into the mixture of GGBS and PCC is expressed as $\mathrm{SO}_{3}$ sulfate content, also in accordance with European standard EN 197-1: 2011 [17]. The mixtures were ground to specific surface area of $400 \mathrm{~m}^{2} \cdot \mathrm{kg}^{-1}$.

\section{Method of testing the resistance of building products and materials to filamentous fungi according to ČSN 72 4310: 1977}

The antifungal activity of the materials such as GGBS, CEM III/A 32,5 N, CEM III/B 32,5 N, CEM III/C 32,5 N, CEM II/A-S 42,5 R, CEM II/B-S 32,5 R, CEM I $42,5 \mathrm{~N}$ and the ternary mixtures of GGBS, PCC and gypsum was tested using the procedure given in the Czech national standard ČSN 72 4310: 1977 [21].

The mould proofness properties expressed as the intensity of fungi growth on building products and materials, are determined by both artificial and natural con-

Table 3. Proportions of GGBS, PCC and gypsum in the ternary mixtures used for testing (in wt. \%).

\begin{tabular}{lccccccccc}
\hline Mixture & 1 & 2 & 3 & 4 & 5 & 6 & 7 & 8 & 9 \\
\hline GGBS & 5 & 20 & 30 & 40 & 60 & 63 & 65 & 70 & 80 \\
PCC & 95 & 80 & 70 & 60 & 40 & 32 & 35 & 30 & 20 \\
Gypsum* & 3.40 & 3.30 & 3.10 & 2.90 & 2.60 & 2.50 & 2.40 & 2.30 & 2.20 \\
\hline
\end{tabular}

* Gypsum is expressed as sulfate content in the form of sulphur trioxide $\mathrm{SO}_{3}$ wt. \% added into the binary GGBS and PCC mixtures. 
tamination, with exposure to the selected testing moulds under the prescribed conditions presented in [21].

The growth media used were as follows:

1) common wort agar containing $1000 \mathrm{ml}$ of fresh wort extract with specific weight of $1.04014\left(10^{\circ} \mathrm{Bg}\right.$ or $5.67^{\circ} \mathrm{Bé}$ ) and $25 \mathrm{~g}$ agar, with $\mathrm{pH}$ adjusted from 5.2 to 5.5 and sterilized;

2) Czapek-Dox agar with glucose containing $3 \mathrm{~g} \mathrm{NaNO}_{3}$, $1 \mathrm{~g} \mathrm{KH}_{2} \mathrm{PO}_{4}, 0.5 \mathrm{~g} \mathrm{MgSO}_{4} \cdot 7 \mathrm{H}_{2} \mathrm{O}, 0.5 \mathrm{~g} \mathrm{KCl}, 0.01 \mathrm{~g}$ $\mathrm{FeSO}_{4} \cdot 7 \mathrm{H}_{2} \mathrm{O}, 30 \mathrm{~g}$ glucose and $25 \mathrm{~g}$ agar dissolved in $1000 \mathrm{ml}$ distilled water, with $\mathrm{pH}$ adjusted from 6.2 to 6.0 and sterilized;

3) Czapek-Dox agar without glucose containing $3 \mathrm{~g}$ $\mathrm{NaNO}_{3}, 1 \mathrm{~g} \mathrm{KH}_{2} \mathrm{PO}_{4}, 0.5 \mathrm{~g} \mathrm{MgSO}_{4} \cdot 7 \mathrm{H}_{2} \mathrm{O}, 0.5 \mathrm{~g} \mathrm{KCl}$, $0.01 \mathrm{~g} \mathrm{FeSO}_{4} \cdot 7 \mathrm{H}_{2} \mathrm{O}$ and $25 \mathrm{~g}$ agar dissolved in $1000 \mathrm{ml}$ distilled water, with $\mathrm{pH}$ adjusted from 6.2 to 6.0 and sterilized.

These are standardly used media for the cultivation of a wide variety of filamentous fungi. In addition, aqueous mineral solution containing $3 \mathrm{~g} \mathrm{NaNO}_{3}, 1 \mathrm{~g}$ $\mathrm{KH}_{2} \mathrm{PO}_{4}, 0.5 \mathrm{~g} \mathrm{MgSO}_{4} \cdot 7 \mathrm{H}_{2} \mathrm{O}, 0.5 \mathrm{~g} \mathrm{KCl}, 0.01 \mathrm{~g} \mathrm{FeSO}_{4} \cdot$ $\cdot 7 \mathrm{H}_{2} \mathrm{O}$ dissolved in $1000 \mathrm{ml}$ distilled water was used as the suspension medium after sterilization.

A mixture of the filamentous fungi Aspergillus niger (CCM 8155), Chaetomium globosum (CCM 8156), Penicillium funiculosum (CCM F-161), Paecilomyces variotii (CCM F-566) and Gliocladium virens (CCM 8042) - pure cultures delivered from the Czech collection of microorganisms - was used for the artificial contamination during testing.

Czapek-Dox agar with glucose in sterile test tubes was used for inoculation, fungal spores growth and the storing of pure fungi cultures designated for testing. Afterwards, two kinds of spore suspensions were prepared: one in a sterile aqueous mineral solution and the other in sterile drinking water. The spore suspensions were prepared from the determined high-grown fungi cultures (not older than 28 days) in this way: $1 \mathrm{ml}$ of the aqueous mineral solution or drinking water was added into the test-tube with the fungus, sharply shaken and poured into a suitable flask with a neck and a rubber stopper. This must be done very quickly to prevent nutrients escaping from the agar to the mineral solution or drinking water. The working spore suspensions cannot be more than 2 hours old, and the final spore concentration in $1 \mathrm{ml}$ of suspension should be from 1 - to 2-times $10^{6}$.

The germinability of the fungal spores is checked by inoculating Czapek-Dox agar containing glucose with the spore suspension, which is placed in the three Petri dishes. If after 6 days, no fungi colonies are growing, the preparation of a new spore suspension is necessary and the test for germinability must be repeated.

The contamination of samples is done by spraying the spore suspension on the testing samples and broths using the sprayer in the incubator. The drops of spore suspensions cannot overlap anywhere on the sample. The maximum quantity of the spore suspension is 0.5 $\mathrm{ml}$ per $100 \mathrm{~cm}^{2}$ of sample surface.

During curing time, the conditions in the incubator would be kept at a temperature of $28 \pm 2{ }^{\circ} \mathrm{C}$ and a relative humidity of $96 \pm 2 \%$.

The samples were prepared by mixing the delivered materials and drinking water in an appropriate ratio to get a fluid paste. This mixture was then poured into forms of circular shape with an average $\varnothing 5.5 \mathrm{~cm}$; the samples were then stored in a laboratory air-condition for 10 days before testing.

Two sets containing 6 samples each were prepared for testing. One set of the samples was tested under artificial contamination with the selected mixture of filamentous fungi, while the other was tested without artificial contamination. Next, two samples were stored in the laboratory air-condition as control samples.

The solid, circular testing samples were placed into the centre of Petri dishes, which contained the stiffened nutrient broths with no pad between the sample and the broth. These samples were then contaminated with the fungal spore suspension in aqueous mineral solution. They were then exposed on the pad into Petri dishes, which contained a $3 \mathrm{~mm}$ column of water on the dish bottom. This $3 \mathrm{~mm}$ column of water had to be continually maintained during testing. These samples were then stored in a laboratory thermostat. The design for testing the mould proofness properties of building products and materials according to [21] is given in Table 4.

The incubation period for the testing is 3 months. A running evaluation of the intensity of mould growth was conducted once per week during the testing, though this was only an orientational evaluation done visually or by means of a stereoscopical microscope.

Table 4. Scheme of testing the mould proofness properties of building products and materials according to ČSN $724310: 1977$ [21].

\begin{tabular}{lccc}
\hline \multirow{2}{*}{ Type of agar } & \multicolumn{2}{c}{ Number of samples } & \\
\cline { 2 - 3 } & $\begin{array}{c}\text { artificial } \\
\text { contamination }\end{array}$ & $\begin{array}{c}\text { natural } \\
\text { contamination }\end{array}$ & Type of spore suspensions \\
\hline wort agar or Czapek-Dox agar with glucose & 2 & 2 & aqueous mineral solution \\
Czapek-Dox agar - without glucose & 2 & 2 & aqueous mineral solution \\
$\quad$ - with no agar & 2 & 2 & drinking water \\
\hline
\end{tabular}


The scale of evaluation of the mould proofness properties of building products and materials according to [21], by which the degree of the fungi growth is expressed by a value from 0 to 5 , is given in Table 5 . The value 0 means that no growth of fungi occurs and the building products and materials possess fungistatic properties; in some cases fungicide properties also occured after the formation of an inhibiting zone in the broth around the sample.

Table 5. Scale of evaluation of the mould proofness properties of building products and materials according to ČSN 724310 : 1977 [21].

\begin{tabular}{cl}
\hline $\begin{array}{l}\text { Degree of } \\
\text { fungi growth }\end{array}$ & Description \\
\hline 0 & No growth of fungi \\
\hline 1 & $\begin{array}{l}\text { The growth of fungi is negligible } \\
\text { (the colonies of fungi are dispersed) }\end{array}$ \\
\hline 2 & $\begin{array}{l}\text { The growth of fungi is gradual } \\
\text { (numerous small fungi colonies which } \\
\text { cover 25 \% of the sample surface) }\end{array}$ \\
\hline 3 & $\begin{array}{l}\text { The growth of fungi is intensive } \\
\text { (fungi colonies cover up to } 50 \% \text { of } \\
\text { the sample surface) }\end{array}$ \\
\hline 5 & $\begin{array}{l}\text { The growth of fungi is very intensive } \\
\text { (fungi colonies cover up to } 75 \% \text { of } \\
\text { the sample surface) }\end{array}$ \\
\hline 5 & $\begin{array}{l}\text { The sample surface is fully covered by } \\
\text { fungi (fungi colonies cover } 100 \% \text { of } \\
\text { the sample surface) }\end{array}$ \\
\hline
\end{tabular}

The final evaluation was carried out by microscopic examination of the intensity of mould growth on the sample surface. The intensity of mould growth was evaluated according to the scale from 1 to 5 given in Table 5.

The mould proofness properties of the building products and materials were evaluated according to [21] as follows:

- the building products and materials are fungicidal mould does not develop on the sample. An inhibiting zone forms on the agar around the sample;

- the building products and materials are fungistatic mould does not develop on the sample. Mould growth on the agar is not affected;
- the building products and materials are not mouldproof (the intensity of mould growth on the sample surface itself is from 1 to 5).

Generally, fungicides are used to destroy, kill or inhibit the growth of fungi or fungal spores. The term „fungicidal effect" means that a particular substance in a particular concentration inhibits the growth of fungi $100 \%$ in that it kills them. The term „fungistatic effect" means a substance has an inhibiting effect on the growth and reproduction of fungi without destroying them, that a particular substance in a particular concentration inhibits the growth of fungi $100 \%$, but it does not kill them, though the material is not invaded by fungi.

\section{RESULTS AND DISCUSSION}

After the 3 months incubation period, the mould proofness properties of the tested samples were evaluated; the results are given in Tables 6 and 7.

The ternary mixtures of GGBS, PCC and gypsum possess different mould proofness properties, tested according to standard ČSN 72 4310: 1977 [21], depending on the amount of GGBS that was added to the mixture. The results imply that the higher the amount of GGBS in the mixture, the more antimicrobially active the particular cement mixture becomes.

The results of mould proofness properties of the ternary mixtures are given in Table 6. With GGBS content in the mixtures of 65 wt. \% and higher, the mould proofness properties of the cements reach 0 degree of fungi growth.

The results for the mould proofness properties of GGBS, blastfurnace cements (CEM III/A 32,5 N, CEM III/B 32,5 N, CEM III/C 32,5 N), Portland-slag cements (CEM II/A-S 42,5 R, CEM II/B-S 32,5 R) and Portland cement (CEM I 42,5 N), prepared from the same raw materials as those of cement mixtures by grinding in the industrial mills, are given in Table 7 . The results again imply that higher the GGBS content in cement, the more antimicrobially active that particular cement is. At GGBS content in the cements of $65 \mathrm{wt} \%$ and more, the mould proofness properties of the cements reaches 0 degree of fungi growth. The mould proofness properties worse than 2 degree of fungi growth cannot be reached in the case of Portland cements, because of the high alkaline surroundings, with $\mathrm{pH}$ of about 12 due

Table 6. Test results of the mould proofness properties of ternary mixtures of GGBS, PCC and gypsum according to ČSN 724310 : $1977[21]$.

\begin{tabular}{lccccccccc}
\hline Mixture & 1 & 2 & 3 & 4 & 5 & 6 & 7 & 8 & 9 \\
\hline GGBS & 5 & 20 & 30 & 40 & 60 & 63 & 65 & 70 & 80 \\
PCC & 95 & 80 & 70 & 60 & 40 & 32 & 35 & 30 & 20 \\
Gypsum* & 3.40 & 3.30 & 3.10 & 2.90 & 2.60 & 2.50 & 2.40 & 2.30 & 2.20 \\
Proofness & 2 & 2 & 1 & 1 & 1 & 1 & 0 & 0 & 0 \\
\hline
\end{tabular}

* Gypsum is expressed as sulfate content in the form of sulphur trioxide $\mathrm{SO}_{3}$ wt.\% added into the binary GGBS and PCC mixtures. 
to the formation of portlandite $\mathrm{Ca}(\mathrm{OH})_{2}$ as a reaction product of cement hydration, which hinders the fungi growth [2, 3]. Microorganisms grow in $\mathrm{pH}$ range of 2.5 to 9 , and the optimum range for many microorganisms is between $\mathrm{pH} 5$ and 7.5. Generally, most fibrous fungi (moulds) require an acidic environment, i.e. $\mathrm{pH}$ lower than 7 . When $\mathrm{pH}$ rises over 9 even a microbicidal (lethal) effect on microorganisms is attained $[2,3]$.

Table 7. Test results of the mould proofness properties of GGBS and cements according to ČSN 72 4310: 1977 [21].

\begin{tabular}{cl}
\hline $\begin{array}{c}\text { Degree of } \\
\text { fungi growth }\end{array}$ & $\begin{array}{l}\text { Products with the mould proofness } \\
\text { properties according to ČSN 72 4310: 1977 }\end{array}$ \\
\hline 0 & $\begin{array}{l}\text { GGBS, CEM III/A 32,5 N*, } \\
\text { CEM III/B 32,5 N, CEM III/C 32,5 N }\end{array}$ \\
\hline 1 & CEM II/B-S 32,5 R \\
\hline 2 & CEM II/A-S 42,5 R, CEM I 42,5 N \\
\hline 3 & - \\
\hline 4 & - \\
\hline 5 & - \\
\hline
\end{tabular}

* CEM III/A 32,5 N (with GGBS content of 65 wt.\%)

The inhibiting zone did not form on the agar around all of the tested samples. This means that GGBS and blastfurnace cements CEM III/A 32,5 N (with GGBS content of 65 wt. \%), CEM III/B 32,5 N and CEM III/C $32,5 \mathrm{~N}$ do not have a fungicidal effect. However, the results showed that cements with GGBS content of 65 wt. $\%$ and more have a fungistatic effect. Moulds did not develop on the samples, but the mould growth on the agar was not affected.

Generally speaking, the products GGBS, CEM III/A $32,5 \mathrm{~N}$ (with GGBS content of 65 wt. \%), CEM III/B
32,5 $\mathrm{N}$ and CEM III/C 32,5 $\mathrm{N}$ are suitable for reaching 0 degree of fungi growth according to standard ČSN 72 4310: 1977 [21]. On the basis of the results, it can thus be stated that the products GGBS, CEM III/A $32,5 \mathrm{~N}$ (with GGBS content of 65 wt. \%), CEM III/B $32,5 \mathrm{~N}$ and CEM III/C $32,5 \mathrm{~N}$ are defined as fungistatic building materials according to ČSN 72 4310: 1977 [21].

The fungistatic effect of GGBS and blastfurnace cements is also declared by the certificates [22-24] issued on the basis of reference testing, which was carried out in an accredited microbiological laboratory at the Textile Testing Institute (Textilní Zkušební Ústav, s.p.) in Brno, Czech Republic, which is an approved certification body.

Table 8 provides the test results of long-term fungistatic efficiency after exposures lasting 2, 3 and 4 times longer, than is required by the methodology in [21] of GGBS and blastfurnace cements CEM III/A $32,5 \mathrm{~N}$ (with GGBS content of 65 wt. \%) and CEM III/B $32,5 \mathrm{~N}$. They show the fungistatic effect of the particular products after long exposure to fungi. Figure 1 shows the appearance of the testing arrangement in Petri dishes after 9-months exposure.

Of course, this long-term testing was not conducted under the exact conditions and requirements of the

Table 8. Results of long-term tests of fungi resistance of the products GGBS, CEM III/A 32,5 N and CEM III/B 32,5 N according to [21] after exposure for 3, 6, 9 and 12-months.

\begin{tabular}{lcccc}
\hline & \multicolumn{4}{c}{ Degree of fungi growth after } \\
\cline { 2 - 6 } & 3 months & 6 months & 9 months & 12 months \\
\hline GGBS & 0 & 0 & 0 & 0 \\
CEM III/A 32,5 N* & 0 & 0 & 0 & 0 \\
CEM III/B 32,5 N & 0 & 0 & 0 & 0 \\
\hline
\end{tabular}

* CEM III/A 32,5 N (with GGBS content of 65 wt. \%)
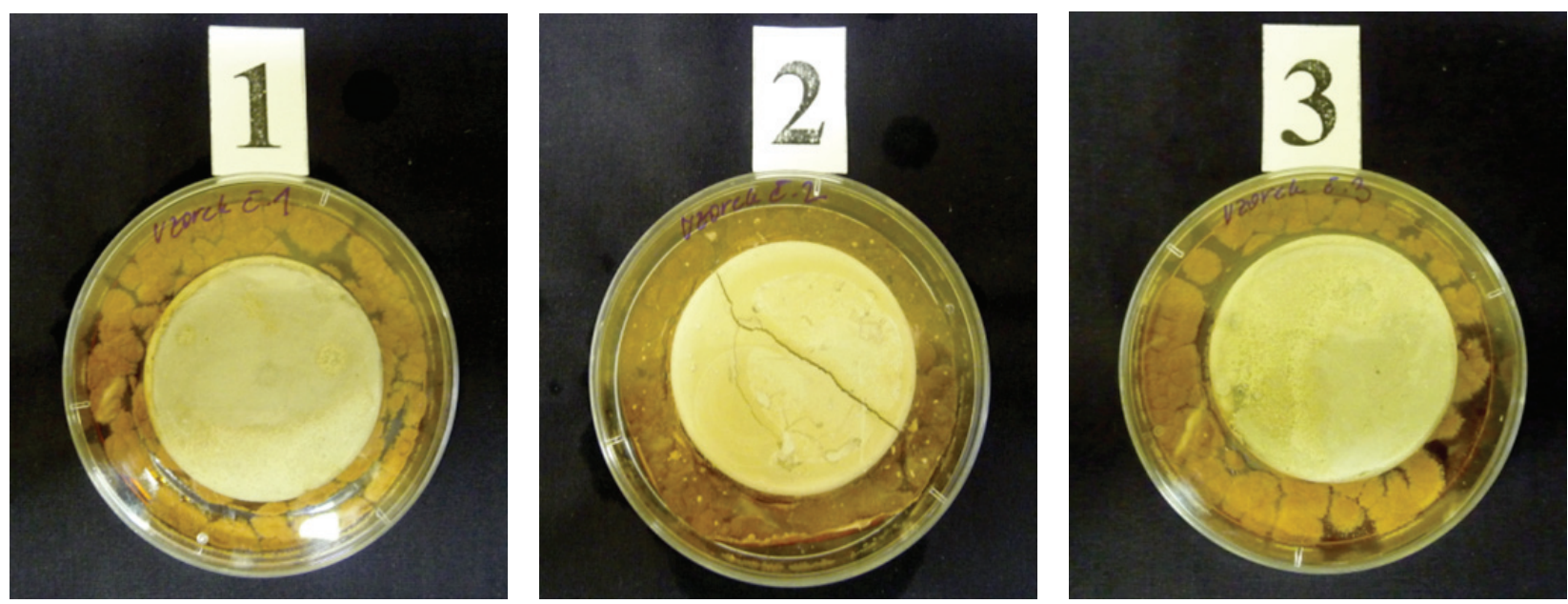

Figure 1. View of the testing arrangement in Petri dishes according to ČSN 72 4310: 1977 [21] after 9-months exposure. The sample is located in the centre as the disc with $\varnothing 5.5 \mathrm{~cm}$, the surroundings are composed of broth media with fungi colonies. No fungi on the surface of the disc of sample. The samples are as follows: 1 - in the centre is the disc of blastfurnace cement CEM III/A 32,5 N (with GGBS content of 65 wt. \%); 2 - in the centre is the disc of ground granulated blastfurnace slag GGBS; 3 - in the centre is the disc of blastfurnace cement CEM III/B 32,5 N. 
methodology in [21]. It must be taken into account that the results could be influenced by the bioviability of the fungi, which could be reduced through consumption of nutrients in the broth media, despite the fact that the testing samples were permanently moisturized to keep the broth media damp thus prolonging the bioviability of fungi as much as possible. The results show the fungistatic effect of the tested products.

GGBS satisfying the requirements of European standards EN 197-1: 2011 [17] and EN 15167-1: 2006 [25] can be used for the production of fungistatic blastfurnace cements with GGBS content of $65-95 \mathrm{wt} \%$ as well as for the production of fungistatic GGBS addition.

Some of GGBS was water leached at $20^{\circ} \mathrm{C}$ and $100^{\circ} \mathrm{C}$ and analysed for the presence of certain hazardous organic substances and heavy metals. The chemical composition of the GGBS water leaches (Table 2) showed that no higher amounts of hazardous organic substances and heavy metals were present in the leaches. However, GGBS increases $\mathrm{pH}$ values of the leaches up to 11.5 , which affects the viability of microorganisms. This effect is similar to the effect of lime during sanitisation (hygienisation). Disinfection by lime at a wastewater treatment plant reduces the number of microorganisms extensively when operated at $\mathrm{pH} 11.2$ [26]. Lime enables the destruction of all pathogens due to the $\mathrm{pH}$ effect it provides (alkaline hydrolysis), combined with the temperature increase that quicklime hydration brings (thermolysis) [27]. Of course, the thermolysis effect can be excluded in the case of GGBS in comparison with lime, but alkaline hydrolysis can be considered as an antimicrobial potential of GGBS. Alkaline hydrolysis $\left(\mathrm{OH}^{-}\right)$results in the destruction of protein-based cellular walls and of enzymes, the destruction of proteins at polypeptide bonds to amino acids and oligopeptides, the destruction of nucleic acids RNA/DNA, the destruction of carbohydrate cell constituents and lipids and the denaturing of enzymes [27].

However, the mechanism of the antimicrobial effects of GGBS should be the subject of further study.

According to the obtained results, the addition of fungistatic GGBS is suitable for achieving long-term fungistatic protection. From a practical point of view, fungistatic GGBS, CEM III/A 32,5 N (with GGBS content of 65 wt. \%), CEM III/B 32,5 N and CEM III/C $32,5 \mathrm{~N}$ are suitable for achieving a mould-free environment. GGBS potentially offers wide application possibilities from preventive use to the purposes of repairing and reconstruction.

\section{CONCLUSIONS}

The main conclusions that can be drawn from this experimental study may be summarized as follows:

- Ground granulated blastfurnace slag (GGBS) is a fun- gistatic building material according to the requirements of ČSN 72 4310: 1977 with mould proofness property 0 .

- No growth of fungi is observed in cement-based products containing GGBS of $65-95$ wt. \% related to the cement binder, with mould proofness property 0 .

- The presence of fungistatic GGBS in CEM III/A $32,5 \mathrm{~N}, \mathrm{CEM}$ III/B 32,5 N and CEM III/C 32,5 N ensures their long-term fungistatic properties.

- Fungistatic cements CEM III/A 32,5 N, CEM III/B $32,5 \mathrm{~N}$ and CEM III/C $32,5 \mathrm{~N}$ are suitable for use in a wide scope of applications aimed at eliminating fungal growth, starting with preventive purposes and ending with repairing and reconstruction works.

\section{REFERENCES}

1. Leemann A., Lothenbach B., Hoffmann C. (2010): Biologically induced concrete deterioration in a wastewater treatment plant assessed by combining microstructural analysis with thermodynamic modeling. Cement and Concrete Research, 40, 1157-1164. doi:10.1016/j.cemconres.2010.03.007

2. George R.P., Vishwakarma V., Samal S.S., Mudali U.K. (2012): Current understanding and future approaches for controlling microbially influenced concrete corrosion: a review, Concrete Research Letters, 3, 491-506.

3. Cwalina B. (2008): Biodeterioration of concrete. Architecture civil engineering environment, 1(4), 133-140.

4. De Windt L., Devillers P. (2010): Modeling the degradation of Portland cement pastes by biogenic organic acids. Cement and Concrete Research, 40(8), 1165-1174. doi: 10.1016/j.cemconres.2010.03.005

5. Magniont C., Coutand M., Bertron A., Cameleyre X., Lafforgue Ch., Beafort S., Escadeillas G. (2011): A new test method to assess the bacterial deterioration of cementitious materials. Cement and Concrete Research, 41(4), 429-438. doi:10.1016/j.cemconres.2011.01.014

6. Neumann T., Dehn F. (2012). Concepts for concrete exposed to acidic fluids. Ne findings, in: $56^{\text {th }}$ Betontage Conference, Germany, pp. 196-197.

7. Coetser S.E., Cloete T.E (2005): Biofouling and biocorrosion in industrial water systems. Critical reviews in microbiology, 31(4), 213-232.

8. Davidovits J. (2011). Application of Ca-based geopolymer with blast furnace slag, a review, in: $2^{\text {nd }}$ International Slag Valorisation Symposium, Leuven, Belgium, pp. 33-49.

9. Giannantonio D.J., Kurth J.C., Kurtis K.E., Sobecky, P.A. (2009): Effects of concrete properties and nutrients on fungal colonization and fouling. International Biodeterioration \& Biodegradation, 63(3), 252-259.

10. Takumi K., Minoru M.: Japanese patent JP 2006327866 A, 2005.

11. Minoru M., Takayuki H., Keisuke N., Shoichi O.: Japanese patent JP 2005139010 A, 2003.

12. Masanori, A.: Japanese patent JP 10025175 A, 1996.

13. Takehiko M., Shinji T., Mitsuru K.: Japanese patent JP 09002859 A, 1995.

14. Martauz P., Strigáč J.: European Patent Application No. EP

Ceramics - Silikáty 60 (1) 19-26 (2016) 
$10177563.3,2009$.

15. Strigáč J., Martauz P., Varečka L., Hudecová D. (2013): in: $1^{\text {st }}$ International Conference on the Chemistry of Construction Materials, ed. Technical University in Berlin, pp 319-322, Germany, Berlin.

16. Martauz. P., Strigáć J.: Utility model SK 5741 Y1, 2010.

17. European standard EN 197-1: 2011, Cement - Part 1: Composition, specifications and conformity criteria for common cements, 2011.

18. Drissen P. (1994): Glasgehaltbestimmung von Huttensand. ZKG Int. 47, 658-663.

19. Tänzer R., Buchwald A., Stephan D. (2015): Effect of slag chemistry on the hydration of alkali-activated blastfurnace slag. Materials and Structures, 48(3), 629-641. doi: 10.1617/s11527-014-0461-x

20. British standard BS 6699: 1992, Specification for Ground granulated blastfurnace slag for use with Portland cement, Appendix D, Method of determining the glass content of ggbs by X-ray diffraction, 1992

21. Czech national standard CSN 72 4310: 1977 - The testing of mould proofness of building products and materials, 1977 (note: former Czechoslovakian national standard until 1. 1. 1993).

22. The certificate No. 10-015, Ground granulated blast fur- nace slag BIOLANOVA - mineral anti-mould addition for cements, mortars and concretes - fungistatic building material, Textile testing institute (Textilní Zkušební Ústav, s.p.) in Brno, Czech Republic 2010.

23. The certificate No. 10-016, Blastfurnace cement BIOCEMENT - CEM III/A 32,5 N - anti-mould cement on the base of blast furnace slag - fungistatic building material, Textile testing institute (Textilní Zkušební Ústav, s.p.) in Brno, Czech Republic (2010).

24. The certificate No. 10-017, Blastfurnace cement STABILIZÁTOR - CEM III/B 32,5 N - anti-mould cement on the base of blast furnace slag - fungistatic building material, Textile testing institute (Textilní zkušební ústav, s.p.) in Brno, Czech Republic 2010.

25. European standard EN 15167-1: 2006 Ground granulated blast furnace slag for use in concrete, mortar and grout. Definitions, specifications and conformity criteria, 2006

26. Grabow W.O.K., Middendorf I.G., Basson N.C.: Appl. and Environ. Microbiol 35, 663 (1978).

27. Remy M. (2009), in: Conference Animal health and welfare: a sustainable solution from industry, ed. European Lime Association (EULA), Belgium, pp. 1-4. 